\title{
Learning Management of Inclusive Elementary School in Samarinda
}

\section{${ }^{1}$ Nur Agus Salim, ${ }^{2}$ Nurul Hikmah, ${ }^{3}$ Eka Selvi Handayani, ${ }^{4}$ Muhammad Zaibi, ${ }^{5}$ M. Azhari,}

\author{
${ }^{1}$ Widya Gama Mahakam Samarinda University, Samarinda, Indonesia, nuragussalim@uwgm.ac.id, ORCID: \\ 0000-0003-4892-2146 \\ ${ }^{2}$ Widya Gama Mahakam Samarinda University, Samarinda, Indonesia, nhikmah923@ yahoo.com, ORCID: \\ 0000-0002-0561-4218 \\ ${ }^{3}$ Widya Gama Mahakam Samarinda University, Samarinda, Indonesia, ekaselvi16@gmail.com, ORCID: 0000- \\ 0001-6151-4388 \\ ${ }^{4}$ Mulawarman University, Samarinda, Indonesia, muhammadzaibi31@ gmail.com, ORCID: 0000-0003-2217- \\ 8718 \\ ${ }^{5}$ Kutai Kartanegara University, Tenggarong, Indonesia, arimuhammad7676@ gmail.com, ORCID: 0000-0001- \\ 8549-2451
}

Article History:Received:11 January 2021; Accepted: 27 February 2021; Published online: 5 April 2021

\begin{abstract}
This research aimed to identify the management of the inclusive learning process in elementary schools in Samarinda. This research focused on the inclusive learning process activities, including material, media, methods, models and learning activities in the classroom, the collaboration between students, relationships between students, teacher-student communication, and student learning outcomes. Data collection techniques used were observation, interviews, and documentation. This qualitative descriptive study results can be concluded that the implementation of learning management in elementary schools in Samarinda has not been carried out maximally. This case is because the application of the inclusive learning in the elementary schools in Samarinda experiences several problems, including the lack of Special Advisory Teachers, the lack of socialization of learning management from the Educational Department to the schools, and the lack of cooperation that exists between schools and Special Schools.
\end{abstract}

Keywords: Learning Management, Inclusive School

\section{INTRODUCTION}

Everyone has the same right to obtain a proper education. As stated in the 1945 Constitution, article 31, paragraph 1, "every citizen has the right to education." It means that citizens have the same right to attain education. In the Law No. 20 of 2003, there is the right to access education for students with special needs as stated on the National Education System article 5 paragraph 2, "citizens who have physical, emotional, mental, intellectual, and social disabilities are entitled to special education.

According to Echol (2003), management is derived from the English word, namely 'to manage,' which means to organize, regulate, and implement. Meanwhile, according to Ibrahim (2012), management is a process consisting of activities in achieving the goal of cooperation (administration) efficiently. Arikunto (2012) said learning management consists of two words, namely management and learning. The word of management comes from the English, namely "administration," which is synonymous with "management," an understanding in a broader scope.

According to Mulyasa, learning (2008) is the process of interaction between students and their environment, so there is a change to better behavior. There are two influencing factors, namely internal and external factors. Meanwhile, according to Hamdani (2017), learning is the process of setting and organizing the environment around students to foster and encourage students to do the learning process. Then, Saputra (2011) explained that the fundamental principle of inclusive education is that all students learn together regardless of their difficulties or differences. Abdurrahman (2006) stated that educational goals are not always programmed, controlled, and measurable. Students can respect each other, collaborate, respect the thoughts and feelings of others, tolerate; those are some examples of educational goals that are not always programmed, controlled, and measured. Extraordinary children should be integrated with other children in general or who are often called normal children to achieve educational goals. Tarmansyah (2009) addressed that inclusive education is carried out according to the type of Children with Special Needs- categorized students; he defined inclusive education is the placement of children with low, moderate, high, and normal levels of disability into regular classes. Learning is conducted in the same class with students' diverse conditions in terms of their intellectual, behavioral, and social attitudes.(Sundqvist \& Hannås, 2020)

All students in inclusive schools can be served by making various adjustments, ranging from the curriculum, infrastructure, educators and education, learning systems to the assessment system. (Alasim, 2020; Crispel \& Kasperski, 2019; Manrique et al., 2018; McKenna et al., 2019; Olsson et al., 2020; Suter et al., 2020) 
Through inclusive education, children with special needs will be allowed to learn together with normal children in regular classes.(Alnahdi \& Schwab, 2020) Therefore, all children will interact with each other and foster a sense of concern for other friends, especially children with special needs. Learning for children with special needs cannot be equated with children in general. Therefore, research conducted by Munk and Agergaad (2015) revealed that we should understand the characteristics of students with special needs based on gender, physical, ethnic background because, in the implementation of learning, they require different treatment. In inclusive schools, normal children and children with special needs learn in one class.(Evaggelia, 2019; Průžek et al., 2020) In addition, Smith (2006) addressed that inclusive education is an educational program that accommodates all students in the same class according to their needs and abilities, including students with special needs.

However, the majority of schools that implement the inclusion program have not made changes and modifications to the curriculum and have not provided facilities that support students with special needs. (Sulasmi \& Akrim, 2020; Sunardi et al., 2011). Curriculum adjustment for students with special needs is very significant because they have different abilities from students in general.(Fareo, 2020; Karr et al., 2020; Mertoğlu, 2020; Muqoddam \& Hendriani, 2020; Theobald et al., 2019) The supporting facilities in the implementation of learning for students with special needs are necessary. (Alasim, 2020) Research conducted by Yusuf, et al. (2011) in 51 elementary schools implementing inclusive programs in four regencies in Central Java revealed that inclusive schools did not carry out the functions and aspects of school management adequately; (5) schools were in dire need of inclusive education management guidelines. Besides, research conducted by Timo Saloviita (2020) in Finland found that teachers' perceptions of inclusive education were shallow. Implementing inclusive education is not easy; many factors become obstacles in its implementation such as facilities, special assistant teachers, policy and a supportive environment.(Alasim, 2020; Crispel \& Kasperski, 2019; Manrique et al., 2018; McKenna et al., 2019; Olsson et al., 2020; Suter et al., 2020)

In Samarinda, there is only one state school that implements an inclusive program, namely Public Elementary School 016 Samarinda. The implementation of the inclusion program in Public Elementary School 016 Samarinda aims to overcome the learning difficulties experienced by students with special needs and extraordinary skills so that they can study together with other students (normal) in regular classes using the same curriculum. Besides, applied learning management must also pay attention to the students' needs individually. For researchers, the existence of elementary schools that organize this inclusion program is interesting to study. The research problem in this study is, "How is the management of learning applied to inclusive schools in Public Elementary School 016 Samarinda? This research aimed to obtain a description of the learning management used in the Inclusive school in Public Elementary School 016 Samarinda. This research focused on the preparation and implementation of inclusive education learning, including learning methods and media, learning materials, learning activities and atmosphere in the classroom, the collaboration between students, student relations, teacher and student communication, and student learning outcomes.

\section{RESEARCH METHODOLOGY \\ Research Method}

This research used a descriptive qualitative research method. The research subjects were the advisory teacher for inclusive students and school principal who teaches and manages in Public Elementary School 016 Samarinda. The research took place at Public Elementary School 016 Samarinda, and the research was carried out for three months. Data collection techniques in this study were observation, interviews, and documentation.

This study employed qualitative data analysis techniques with three components of analysis, including data reduction, data presentation, and concluding (2005). The validity test conducted on the data was triangulation. (Carlson, 2010; Denzin, 2012) Triangulation is a data validity checking technique that uses another thing for checking purposes or as a comparison of that data. (Denzin, 2012) Triangulation can be divided into four, namely data triangulation, researcher triangulation, theory triangulation, and method triangulation. In this study, researchers conducted triangulation of the data while also using member checks. A member check is undertaken to provide an opportunity for the subject to immediately correct data if there are errors.

\section{RESEARCH RESULTS AND DISCUSSION \\ Research Results}

Public Elementary School 016 Samarinda is an Inclusive School located on Jalan Antasari Samarinda. Learning management in inclusive schools that were studied included class atmosphere, collaboration, and relationships between students and teacher, and student communication, learning methods applied, media or assistive devices, learning materials, learning outcomes, learning activities, and student psychological condition towards learning.

\section{The Results of Interview with School Principal}


The principal said that there were no specific criteria or conditions for enrolling in inclusive schools; what is essential is that there are students who have special needs and abilities from the Principal and his supervisors (educator). Special Supervising Teachers were less than optimal. The use of methods, media, curriculum, and Lesson Plan was similar to regular students, but there had been a slight change adapted to the needs of students.

During the new school year and registration period, the school assesses and identifies students who have special needs. This assessment includes physical and academic tests. There are some criteria for Children with Special Needs that can attend Public Elementary School 016 Samarinda; this case is adjusted to the ability of Special Supervising Teachers. After identification, the students' parents are invited to consult and provided an understanding that their children are participating in the inclusion program.

Communication that occurs between children with special needs and other students, as well as teachers, is well established. Communication that exists between teachers and students with special needs is more common because of a particular guidance program. The existence of children with special needs in the classroom does not affect the learning outcomes of other students.

\section{The Results of Interview with Special Supervising Teacher for Inclusive Students}

The teachers who supervise the inclusive students when teaching for the first time in an inclusive school get confused because they do not yet know the specific ways on how to handle inclusive children. However, on the other hand, the teachers feel happy because they can help students with special needs to get an education. Children with special needs do not have to go to an Extraordinary School.

There are two students with special needs in each class. There were four names categorized as children with special needs, namely Ali and Daffa; they were active students and experience learning delays. Meanwhile, Ina and Egi were students who actively asked questions, quickly understood what was explained, and could answer when they were asked questions. The learning process was carried out classically, so learning followed regular learning, but the students with special needs were given a special approach. The Lesson Plan used was an ordinary lesson plan for learning in general.

The learning process occurred in class run regularly because inclusive students were provided with a distinctive approach to facilitate the students' abilities. In the learning process, teachers must be patient and painstaking or resilient, because especially first grade students are still small; children with special needs cannot yet know how to hold a pencil correctly, cannot write and are often crowded or fighting in class; therefore, overcoming those problems is by giving special time for children with special needs.

The method applied in learning is a general method and approach to students and parents. By applying these methods, there is an increase in students' abilities. In daily activities and learning, there is no particular media used; this case is because the students with special needs experience learning delays. The learning outcomes of students with special needs are far below those of their peers. The main factor they experience learning delays.

Schools apply a general curriculum. However, teachers reduce the material given to students with special needs. The reduction of this material is based on the teacher's discretion by looking at students' abilities. Although there has been a reduction in material and minimum completeness criteria, sometimes students with special needs cannot reach the minimum completeness criteria.

Collaboration between students was well established, as is the communication that occurred between teachers and students. The implementation of the learning process in the Inclusive School in Public Elementary School 016 Samarinda had constraints on teacher resources as homeroom teachers who rarely attended upgrading.

\section{The Results of Interview with Inclusive Students' Parents}

The parents interviewed were Daffa's and Egi's mothers. Daffa's mother told the interviewer that it was difficult to deal with Daffa because she was screaming and could not be banned. Nevertheless, during therapy in Surabaya, Daffa seemed rather calm, no longer likes screaming and keeping food not to eat sweet foods. Daffa obeyed what her mother said but was slow to do the task of answering the questions. Daffa has an excellent ability in terms of coloring pictures. Meanwhile, Egi's mother told the interview that Egi was actively asking and moving; if he was reprimanded, he would immediately be angry and shout. However, Egi has a passion for learning to do assignments from school and likes to recite.

\section{The Results of Interview with Inclusive Students}

Two male students with special needs were interviewed, namely Daffa and Egi. Daffa likes raising cats and rabbits, drawing, and coloring. Daffa lives on Jakarta street and has one brother. Daffa likes math. Meanwhile, Egi also likes drawing and coloring. Egi likes religious subjects. Daffa and Egi actively talk, move, and like to ask questions. 


\section{The Observation Results in Learning Process}

In the initial activities of the implementation of inclusive learning, the teacher started with greetings, conducting apperception activities tailored to the subjects delivered. In the core activity in learning, an active interaction occurred between the teacher and students; the teacher engaged students in the learning process. The teacher used conventional methods or lectures, questions, and answers and demonstrations in learning. In the learning process, the teacher accompanied students with special needs to participate in learning.

The classroom situation, when learning seemed to be active, full of enthusiasm; the level of student development caused this condition. Initially, this class was not like the inclusive class, but after observing, two students had special needs. One of them was Ali sitting in the middle seat. From the researcher's observations, Ali was one of the active students, who were sometimes slow in learning, liked to daydream not paying attention to the teacher, could not answer questions, sometimes joked and annoyed friends next to him. Meanwhile, Ina had a passion for doing the task from the teacher. The cooperation between students was good, including Ina and her friends. This collaboration could be seen when Ina's friend helped Ina in doing the assignment given by the teacher. The material delivered by the teacher to Ina and other students was the same; Sometimes, the teacher gave special guidance to her. The provision of this exceptional guidance sometimes caused jealousy for other students.

The last activity in this study was by reinforcing the material, evaluating the material, and implementing the following-up of the learning through assignments done at home. For students with special needs, an explanation was provided after school so those students could understand the material.

The spatial arrangements for the inclusive class were carried out in such a way, like any other class, aiming to create a pleasant environment. Each inclusive homeroom teacher paid attention to the cleanliness, neatness, and accuracy of the placement of decorations in the classroom. The spatial arrangements took into account the students' convenience in the learning process. They strove to be able to assist students in learning to provide facilities of learning in the classroom and playing in the school environment so that students did not feel bored.

\section{Students' Learning Outcomes}

Learning outcomes are the results showing the students' ability in learning in terms of cognitive, affective, and psychomotor. Inclusive students' learning outcomes report forms were the same as other students' learning outcomes reports in general. However, in inclusive students' learning outcomes reports, there was an assessment of inclusive students. This assessment contained the student's identity, physical condition, students' abilities, and developments in the semester. This student assessment was carried out by the homeroom teacher and the principal.

Basically, the evaluation in the inclusive class aims to find out the development of learning outcomes. The evaluation of learning in inclusive classes was carried out in various forms of evaluation, including daily tests, midterm tests, and general tests conducted at the end of each year. The type of tests given to students with special needs was clearly determined according to the stages of learning so that the results of the evaluation provided an objective picture of students' learning outcomes. In addition, the tests given to students were comprehensive, meaning that of all submitted subjects would be summarized in the evaluation.

\section{Discussion}

From the above research results, this study discusses assessing students, the situation of inclusive classes, methods, and media in learning, material and learning outcomes of inclusive students, learning activities occurring in class, special guidance programs, and school obstacles in implementing inclusive education. Schools, as a media for the ongoing educational process, need to provide a particular space for children with special needs in obtaining professional education. (Spoede et al., 2016)

Admission of new students at Public Elementary School 016 Samarinda through the assessment stage was carried out by homeroom teachers and school principals. The assessment process was conducted so that the teacher early identified the special needs experienced by each student. As an inclusive elementary school, Public Elementary School 016 Samarinda could not accept all students with special needs who were registering. Public Elementary School 016 Samarinda only received students with special needs according to the ability of the Special Supervising Teacher. The special supervising teachers for students with special needs must have competence in detecting and providing interventions to students with special needs (Spoede et al., 2016). The special supervising teachers available in Public Elementary School 016 Samarinda did not have specialized competencies, so not all students could be accepted. Students with special needs recently accepted by this school included special needs in the types of physical impairment, mild mental retardation, speech difficulties, and learning delays. Meanwhile, Public Elementary School 016 Samarinda could not accept students with autism, visual impairment, hearing impairment, and speech impairment.

Special supervising teachers must have complex abilities not only in understanding the learning process for students with special needs but also in preparing for their services. According to Brownell et al. (2010), 
special supervising teachers must master sophisticated teaching knowledge and practices. Preparations for teaching special education must be built on the existing knowledge base and demonstrate competence in classroom practice. In supporting teachers' competence in implementing special education, the government needs to reinforce training or special education. Brownell (2010) argued that motivating general-education teachers to become special educators requires fundamental reforms in school practices, incentives for teachers, and teacher education.

Gersten (2001) mentioned several significant factors to consider in increasing the retention and commitment of special supervising teachers. The main negative factor is stress due to job design. The support obtained by the principal or other teachers in the school can help to reduce this stress. Another critical factor is the feeling that special educators learn at work, both formally and informally, through collegial networks. Principal's support, both morally and financially, in organizing inclusive schools, is needed in enhancing teachers' motivation in education.

The state of the inclusive class, when learning taking place regularly, was similar to a regular class. Normal here was according to the level of student development. The presence of students with special needs in class did not disturb other students. Students with special needs, on average, sit at the front of the bench; this setting of the seat was intended so that teachers more easily monitored students' progress, and also students could pay more attention to the teacher's explanation. However, there were two students with special needs and sit in the back of the bench. Based on the information from the homeroom teacher, both students with special needs were usually disrupting the learning process.

The implementation of learning, of course, cannot be separated from the making of the Lesson Plan. The principal created a discourse so that the teacher made an Individual Learning Program. The making of the Individual Learning Program was intended so that teachers had a reference in implementing learning. Most teachers did not make the Individual Learning Program due to the busy schedule of teachers who were concurrently serving as Homeroom Teachers and Special Supervising Teachers. On the other hand, some teachers were still confused because they recognized that there should be a special curriculum and Individual Learning Program applied, but the Office had not provided explicit provisions; finally, those teachers still used the lesson plans in general.

The method applied in the learning process was the same as the regular learning, but when students with special needs could not follow the learning, the teacher provided a different method. The method often used by teachers was the particular approach method. However, in its application, this method did not run smoothly because of the teacher's busyness in carrying out their duties as a homeroom teacher. The learning in management class and the practice of student discipline in inclusive schools must be implemented well. The same disciplinary practices used throughout schools must also be used in special education programs, regardless of whether the student is a student with a disability or a student at risk of school failure (Idol, 2006)

The lesson delivered by the teacher to students was adjusted to the level of student development. Most of the teachers reduced the burden of material given to students with special needs. This reduction was approved by the principal based on the needs of each student. The minimum completeness criteria applied to students with special needs were also different from the criteria of regular students; there was a reduction in its implementation. The decline in standards relied on the ability of each student with special needs. However, most of the students with special needs still had not been able to reach the desired target.

Learning conducted in Public Elementary School 016 Samarinda referred to the Lesson Plan made by that elementary school. In the learning process, teachers took the time to monitor and guide students with special needs. Learning activities run smoothly and almost in accordance with the teachers' expectations. The presence of students with special needs in inclusive classes did not make the learning inhibited. On the contrary, their existence made other students understood the difference and helped with pleasure.

In handling inclusive school, Public Elementary School 016 Samarinda had a particular advisory program for students with special needs. This program was designed so that students with special needs could catch up with regular students. The special advisory was carried out by regular teachers who concurrently became Special Supervising Teachers. Based on the existing schedule, the advisory should be conducted routinely. However, because of each teacher's busyness, the advisory did not run regularly. In addition to special advisory provided by the teacher, the principal also held special advisory classically. In this classical advisory, students were guided by the principal. Classical guidance was usually carried out in the principal's office and in uncertain times, sometimes once every two weeks, or once a month.

There were several problems in conducting inclusive schools. This problem came from inside and outside of school. The obstacle coming within the school was the lack of Special Supervising Teacher in Public Elementary School 016 Samarinda. The Special Supervising Teachers in that elementary school were already available, but they were the regular teachers who also worked as Special Supervising Teacher. Because of the busyness in handling regular classes and guiding students with special needs, those teachers sometimes forgot to provide guidance. In addition, the level of teachers' knowledge about inclusive schools was still lacking. According to information, the teachers had only participated in upgrading on inclusive schools three times, and 
there had been no following-up from the Educational Department. The upgrading only discussed inclusive schools in general, not about the learning, lesson plans, and curriculum that must exist in inclusive schools. Also, there was still another problem, namely a lack of cooperation system between Public Elementary School 016 Samarinda and the nearest Extraordinary School. Up to now, no party from Extraordinary School comes to visit Public Elementary School 016 Samarinda to conduct monitoring and exchange information with teachers about how special services should be provided to students.

\section{CLOSING}

Conclusion

Inclusion learning planning was prepared by the homeroom teacher and special supervising teacher, without distinguishing between students with special needs and regular students. Several teachers regarding classroom conditions carried out planning because the learning place's environment significantly influences learning outcomes. The implementation of inclusive learning was undertaken simultaneously in one class. Still, students with special needs were provided additional activities after school and assignments to be done at home so students could understand the material presented.

The management of inclusive learning in Public Elementary School 016 Samarinda included curriculum and Lesson Plan applied, learning activities, methods and media used, special advisory programs, and student learning outcomes. Curriculum and Lesson Plan implemented in Public Elementary School 016 Samarinda were mostly general curriculum and Lesson Plan. Learning activities took place smoothly as planned according to the existing Lesson Plan, but there was exceptional guidance for students with special needs when knowing activities running. The teacher used an individual approach for students with special needs. The obstacle faced by the special supervising teachers in implementing the particular guidance program was their busyness and lack of knowledge about students with special needs. Students with special needs were below the average of regular students, but there were two students with special needs who could take regular lessons. Based on the discussion presented previously, it can be concluded that the implementation of the learning management of the inclusive school in Public Elementary School 016 Samarinda has not been carried out maximally. This case was Public Elementary School 016 Samarinda experienced some problems, including the lack of Special Supervising Teachers and cooperation between schools and great schools.

\section{Recommendation}

Public Elementary School 016 Samarinda is recommended to guide the implementation of inclusive programs in the school and look for Special Supervising Teachers. They have skills in the field of handling children with special needs. Teachers should have more knowledge about learning management in inclusive schools. Teachers can participate in scientific activities, such as seminars, workshops, training, classroom action research, by collaborating with Extraordinary School teachers and finding references from various sources. Besides, teachers are expected to be able to apply knowledge to their daily lives.

The government should provide more explicit instructions to schools that have an inclusive program to implement the inclusive education program comprehensively. Also, special supervising teachers should be added in inclusive schools. The government can hold workshops or training for special supervising teachers. For researchers who will carry out research that is almost the same as this research, it is suggested that they can examine other aspects of management in inclusive schools in depth.

\section{REFERENCES}

1. Abdurrahman, M. (2006). Pendidikan Bagi Anak Berkesulitan Mengajar. Pusat Perbukuan Departemen Pendidikan dan Kebudayaan.

2. Alasim, K. (2020). Inclusion Programmes for Students Who are Deaf and Hard of Hearing in Saudsi Arabia: Issues and Recommendations. International Journal of Disability, Development and Education, 67(6), 571-591. https://doi.org/10.1080/1034912X.2019.1628184

3. Alnahdi, G. H., \& Schwab, S. (2020). Inclusive education in Saudi Arabia and Germany: students' perception of school well-being, social inclusion, and academic self-concept. European Journal of Special Needs Education, 1-14. https://doi.org/10.1080/08856257.2020.1823163

4. Arikunto, S., \& Yuliana, L. (2012). Manajemen Pendidikan: Edisi Revisi. Graha Cendikia.

5. Brownell, M. T., Sindelar, P. T., Kiely, M. T., \& Danielson, L. C. (2010). Special education teacher quality and preparation: Exposing foundations, constructing a new model. Exceptional Children, 76(3), 357-377. https://doi.org/10.1177/001440291007600307

6. Carlson, J. A. (2010). Avoiding Traps in Member Checking. The Qualitative Report, 15, 1103-1113.

7. Crispel, O., \& Kasperski, R. (2019). The impact of teacher training in special education on the 
implementation of inclusion in mainstream classrooms. International Journal of Inclusive Education, O(0), 1-12. https://doi.org/10.1080/13603116.2019.1600590

8. Denzin, N. K. (2012). Triangulation 2.0*. Journal of Mixed Methods Research, 6(2), 80-88. https://doi.org/10.1177/1558689812437186

9. Echols, J. M. (2003). An English-Indonesia. PT. Gramedia.

10. Evaggelia, B. (2019). 'Specialization in ICTs and Special Education: Psychopedagogy of Integration. Democritus University ff Thrace.

11. Fareo, D. D. O. (2020). Prospects and Challenges of Inclusion of Children with Disabilities into Regular School Setting in Nigeria. Saudi Journal of Humanities and Social Sciences, 5(6), 269-273. https://doi.org/10.36348/sjhss.2020.v05i06.001

12. Gersten, R., Keating, T., Yovanoff, P., \& Harniss, M. K. (2001). Working in Special Education: Factors that Enhance Special Educators' Intent to Stay. The Council for Exceptional Children, 67(4), 549-567.

13. Hamdani. (2017). Strategi Belajar Mengajar. Pustaka Setia.

14. Hole, Y., \& Snehal, P. \& Bhaskar, M. (2018). Service marketing and quality strategies. Periodicals of engineering and natural sciences,6 (1), 182-196.

15. Ibrahim, B. (2012). Manajemen Peningkatan Mutu Sekolah Dasar. Bumi Aksara.

16. Idol, L. (2006). Toward Inclusion of Special Education. Remedial and Special Education, 27(2), 77-94. https://doi.org/10.1177/07419325060270020601

17. Karr, V., Hayes, A., \& Hayford, S. (2020). Inclusion of Children with Learning Difficulties in Literacy and Numeracy in Ghana: A Literature Review. International Journal of Disability, Development and Education, OO(00), 1-15. https://doi.org/10.1080/1034912X.2020.1792419

18. Manrique, A. L., Dirani, E. A. T., Frere, A. F., Moreira, G. E., \& Arezes, P. M. (2018). Teachers' perceptions on inclusion in basic school. International Journal of Educational Management.

19. McKenna, J. W., Solis, M., Brigham, F., \& Adamson, R. (2019). The Responsible Inclusion of Students Receiving Special Education Services for Emotional Disturbance: Unraveling the Practice to Research Gap. Behavior Modification, 43(4), 587-611. https://doi.org/10.1177/0145445518762398

20. Mertoğlu, H. (2020). Views of Preservice Primary School Teachers' on Inclusion and Differentiated Science Experiments. Journal of Education and Learning, 9(3), 47. https://doi.org/10.5539/jel.v9n3p47

21. Mulyasa. (2008). Kurikulum Berbasis Kompetensi. Remaja Rosdakarya.

22. Munk, M., \& Agergaard, S. (2015). The processes of inclusion and exclusion in physical education: A social-relational perspective. Social Inclusion, 3(3), 67-81. https://doi.org/10.17645/si.v3i3.201

23. Muqoddam, F., \& Hendriani, W. (2020). The Impact of Peer-mediated Intervention on Children with Special Needs in Inclusion Classroom. TAZKIYA (Journal of Psyhology), 8(2).

24. Olsson, I., Sand, M. L., \& Stenberg, G. (2020). Teachers' perception of inclusion in elementary school: the importance of imitation. European Journal of Special Needs Education, 35(4), 567-575. https://doi.org/10.1080/08856257.2019.1709704

25. Průžek, M., Cihová, I., Novak, D., Wang, X., Vašíčková, J., Tománek, L', \& Antala, B. (2020). Inclusion in physical education on the basis of opinions of high school female students from Slovakia, Czech Republic and Croatia. Journal of Physical Education and Sport, 20(3), 1538-1542. https://doi.org/10.7752/jpes.2020.03211

26. Saloviita, T. (2020). Attitudes of Teachers Towards Inclusive Education in Finland. Scandinavian Journal of Educational Research, 64(2), 270-282. https://doi.org/10.1080/00313831.2018.1541819

27. Saputra, M. (2011). Perbedaan Daya Serap Belajar Anak Berkebutuhan Khusus dengan Anak Normal Kelas V Sekolah Dasar Inklusi Kabupaten Grobo. Universitas Kristen Satya Wacana.

28. Smith, J. D. (2006). Inklusi, Sekolah Ramah Untuk Semua. Nuansa.

29. Spoede, J. T., Fontenot, J. C., \& Simpson, C. (2016). The Role Of The Special Educator In The Inclusive Classroom. Advances in Special Education, 32, 21-38. https://doi.org/http://dx.doi.org/10.1108/S0270-401320160000032004

30. Sulasmi, E., \& Akrim, A. (2020). Management Construction of Inclusion Education in Primary School. Talent Development \& Excellence, $12(1), \quad 334-342$. http://search.ebscohost.com/login.aspx?direct=true\&db=s3h\&AN=144307167\&lang=ja\&site=ehost- 
live

31. Sunardi, Yusuf, M., Gunarhadi, Priyono, \& Yeager, J. L. (2011). The Implementation of Inclusive Education for Students with Special Needs in Indonesia. Excellence in Higher Education, 2(1), 1-10. https://doi.org/10.5195/ehe.2011.27

32. Sundqvist, C., \& Hannås, B. M. (2020). Same vision-different approaches? Special needs education in light of inclusion in Finland and Norway. European Journal of Special Needs Education, 1-14. https://doi.org/10.1080/08856257.2020.1786911

33. Suter, J. C., Giangreco, M. F., \& Bruhl, S. A. D. (2020). Special Education Personnel Absences in Inclusion-Oriented Schools: Implications for Building Effective Service Delivery Models. Remedial and Special Education, 41(6), 341-351. https://doi.org/10.1177/0741932519865617

34. Sutopo, H. . (2005). Metodologi Penelitian Kualitatif. Sebelas Maret University Press.

35. Tarmansyah. (2009). Karakteristik Anak Berkebutuhan Khusus. Universitas Negeri Padang Press.

36. Theobald, R. J., Goldhaber, D. D., Gratz, T. M., \& Holden, K. L. (2019). Career and Technical Education, Inclusion, and Postsecondary Outcomes for Students With Learning Disabilities. Journal of Learning Disabilities, 52(2), 109-119. https://doi.org/10.1177/0022219418775121 